with those of The Bohdan Khmelnytsky National University of Cherkasy and Pavlo Tychyna Uman State Pedagogical University. It should be noted that in Great Britain, more academic hours are allocated for the disciplines in the field of environmental studies, compared to Ukraine. Besides, in British universities students get more time for independent and scientific work. One more difference is that British graduates work in biomedical laboratories, hospitals, etc. as distinct from Ukrainian colleagues, who are usually hired as school teachers. It has been concluded that the environmental training in Ukraine should be performed in the following directions: expansion of hours for environmental disciplines and the number of subjects of the environmental sphere (for example, implementation of subjects "Environmental Development of a Child" and "Socialization of a Child" into the training course of students majoring in "Primary education"), increasing the financing, etc. The following ideas taken from British experience should be implemented into the educational system of Ukraine (particularly, in the field of environmental training): creating the conditions for lifelong environmental learning of teachers, student-centered approach and encouraging students to take part in scientific activities, adoption of methods of conducting different types of lessons (lectures and practicals), as well as IT methods (online discussions, online presentations, etc.). It should be concluded that the study of the specificity and experience of other countries in all spheres of life in general and education in particular will definitely contribute to the improvement of the state in all its spheres.

Keywords: training, teachers, environmental education, Great Britain, Ukraine.

Подано до редакиії 25.02.2017

UDC: 378.147.091.33-027.22:055.336.2

DOI: https://doi.org/10.24195/2414-4665-2017-2-22

Tetiana Koknova,

PhD (Candidate of Pedagogical Sciences), associate professor, Roman and Germanic Philology Department, Luhansk Taras Shevchenko National University,

1, Gogol square, Starobilsk, Ukraine

\title{
IMPLEMENTATION OF PLAY-BASED LEARNING ACTIVITY AS A TOOL TO DEVELOP STUDENTS' PROFESSIONAL COMMUNICATIVE COMPETENCE WITHIN UNIVERSITY COURSE "ENGLISH FOR SPECIFIC PURPOSES"
}

One of the most effective ways to develop students' ability to find, extract and process information from the great variety of authentic sources is the implementation of some interactive forms and methods into the studying process and its theoretical and practical enrichment. In this research the play-based learning activity is understood as the combination of the following three components: playing (stimulating emotional emancipation and exalting the participants, fulfilling their ambitions, expressing their opinions creatively and inspiring interaction between them); educational (aiming to enrich students' knowledge, abilities, skills and experience) and professional (providing the opportunity for teachers to simulate a variety of professional situations). Professional communicative competence is considered to be the combination of knowledge, skills and experience that students of different specialties require to have in order to carry out their professional activities. In order to check the efficiency of the playbased learning activity in the development of students' professional communicative competence we have conducted the experiment, which was held in Luhansk Taras Shevchenko National University (on the basis of Roman and Germanic Philology Department). The study involved 64 second year students of the Foreign Language Department who were divided into two groups: experimental group (32 students) and control group (32 students). 32 students of the experimental group were involved into the experiment with implementing the play-based learning activity in the curriculum and the students of the control group continued studying in their usual way. The research results have shown the effectiveness of play-based learning activity implementation within the university course "English for Specific Purposes" to develop the students" professional communicative competence.

Keywords: play-based learning activity, pedagogical method, the development of professional communicative competence, "English for specific purposes" (ESP), university students, major, specialty.

\section{Introduction}

The countries' commitment to the international community has led to a sharp increase in the flow of information, the role of the intercultural communication, the growth of economics and industrial internationalization. It contributes to the development of cultural and political role of specialists in many areas of public life. Trying to establish national and cultural identity, in the face of global mobility, the university students of different specialties are challenged to maintain the atmosphere of cooperation and inter-cultural dialogue, adjusting the extralinguistic communication, and to ensure the success of multicultural dialogue. The solution to these problems demands the development of professional communicative 
competence of the university students which is based on the competence approach and the implementation of modern teaching technologies into the course "English for specific purposes" (ESP). Since 2016 the British Council involved eighteen Ukrainian higher establishments into the project "English for university students of different specialties". They constantly promote support and help in order to implement the latest educational trends into the process of training future specialists.

The scientists have been paying special attention to process of future specialists' development in higher education (for example, A. Aleksyuk, S. Archangelsky, S. Sysoiev, S. Kharchenko, etc.). The issues of the individual's professional development are represented in the works of S. Batyshev, V. Bodrov, L. Mitin, etc. The effectiveness of gaming techniques in higher education is considered by V. Bederhanova, D. Kavtaradze, J. Ladenko, V. Petrusynskiy, P. Pidkasystiy, S. Shmakov and others. The theory and practice of play-based learning activity in business education and management are represented in the works of J. Belchykov, M. Birshtein, F. Hallyamov, V. Platov, etc.

Despite the contribution which was made by some scientists in solving the problem of professional communicative competence development by means of play-based learning activity there are some contradictions which must be considered. First of all, the labor market requires specialists with the highly-developed communicative competence but unfortunately many universities in Ukraine cannot meet this demand. Secondly, play-based learning activity has a significant potential though this method is not widely used in the educational process in Ukraine.

Thus, the paper aims to check the effectiveness of play-based learning activity in the development of students' professional communicative competence.

\section{Methods}

The pedagogical experiment was used as an empirical method to achieve the goal of the research. It was carried out in Luhansk Taras Shevchenko National University for the second year students (specialty "Secondary School teachers", "Tourism" and "Hotel and Catering service"). The development of the professional communicative competence by means of the play-based learning was implemented into the university course "English for specific purposes". The university teachers of the foreign language department were involved into the experimental process in 2016-2017.

\section{Discussion}

One of the most effective ways to develop students' ability to find, extract and process information from the great variety of authentic sources is the implementation of some interactive forms and methods into the studying process and its theoretical and practical enrichment. The analysis of the scientific and educational literature indicates that one of the most promising methods of teaching is play-based learning activity. It provides a close connection between theoretical knowledge and their use in real life (practical knowledge) creating the conditions which resemble real situations of employees at work. In such a way, teachers can ensure the development of the future specialists' professional communicative competence (the formation of students' active role, their ability to make independent decisions in a variety of professional situations, etc.).

While analysing the term "play-based learning activity" in the scientific literature, a list of closely connected terms was found: critical (simulated) learning environments (J. Beckham \& M. Watkins) [1]; experiential learning (J. Ernst) [2]; project-based learning (C. Zafirov) [3]; active learning strategies (F. Herreid, N. Schiller) [4]; game-based pedagogies (R. Dyer) [5].

The play-based learning activity has a great potential for the development of the professional communicative competence in university students of different specialties. In this research the play-based learning activity is understood as the combination of the following three components: playing (stimulating emotional emancipation and exalting the participants, fulfilling their ambitions, expressing their opinions creatively and inspiring interaction between them); educational (aiming to enrich students' knowledge, abilities, skills and experience) and professional (providing the opportunity for teachers to simulate a variety of professional situations). Therefore, within the scope of studies, the play-based learning activity is understood as a specifically organized type of cognitive activity mediated by common interaction. It includes playing, educational and professional components focused on the development of the professional communicative competence in university students of different specialties.

It should be noted that in this study professional communicative competence is considered as the combination of knowledge, skills and experience that students of different specialties require to have in order to carry out their professional activities. According to the Pavlenkov, the professional communicative competence has three components [6, p.11]. The first one is linguistic (the ability to read, listen, write and speak in English according to the specific professional needs); the second one is pragmatic (the ability to decode and decipher verbal and nonverbal messages); and the third one is sociocultural (the knowledge about the norms of behavior in the multicultural society, tolerance).

It is significant to mention that the curriculum of the ESP course should not be changed. The impact is focused only on the method of presenting the information using the play-based learning activity as much as possible during classes. In order to achieve the required effect, it is necessary to pass the stages, which coincide with the logic of the process of the individual's professional development [7]. According to Verbizkyi's theory [7], three stages of developing professional communicative competence have been formulated by means of the play-based learning activity during the university course "English for Specific Purposes" which is taught to the university students of different specialties. 
The task of the first stage (preparation) is to involve students in learning process in order to adapt them to the new environment, different requirements and all kinds of work during the course. In this stage the professional activity and the features of the working process (i.e. the main tasks, work order, duration of the working process, etc.) should be provided.

The process of developing the professional communicative competence by means of play-based learning activity should be supported by macro contexts (socioeconomic conditions, cultural differences) and micro contexts (team, partners, employers, customers, etc.). In this stage, students have an opportunity to learn more about their future occupation. This step helps them to form the professional communicative competence and learn its unique features. Concerning the information mentioned above it is implemented to organize the students' psychological training in order to use the general provision and clear guidelines to maintain correct professional communication and model a consistent and clear algorithm of the specialist's behavior.

During the course students perform tasks in a form of the play where they have an opportunity to analyze professional activity and become familiar with its specific features in order to have a clear understanding of the profession and the results that they need to achieve at the end of the course. While learning new words and grammar material students may act out a large amount of dialogues regarding the professional contexts (greetings and farewells, self-presentation, the company's presentation, job interview, business phone call, negotiations, etc.). Students' dramatization of dialogues in a form of a game can display different conditions of the future job (e.g. noise, emotional stress, etc.) and show the connection between external factors and their influence on the working process.

The task of the second stage (education and development) is to focus on the students' understanding of the main problems that happen to them on the path to selfimprovement. Students have to set themselves a series of goals to overcome difficulties, develop an improvement work plan and realize that they can enhance their professional communicative competence by means of internal resources thereby developing the strategies for improving this competence in some specific professional situations.

In fact, the second stage is divided into three substeps. The first one aims to introduce the variability of professional situations, including the elements of uncertainty, the lack of necessary information and the compliance with the connection between the requirements for professional communicative competence and the level of students' professional maturity.

Students analyze professional communicative competence in the process of the play-based learning activity in order to see the gaps in their knowledge that are needed to be fulfilled, gain experience and develop professional qualities. During this sub-step, students can regularly do self-examination, self-diagnosis and self-control. The play-based learning activity tries to correlate demands that are required by students' future profession with their individual professional communicative skills that have been formed before. In such a way future specialists will be able to find essential professional communicative skills which they might need further in their work.

For example, the students watched the videos where two Elementary school teachers were working with 6-8 year old children. Later, students were divided into groups, where they had to find the reply justifying the following questions: "What professional communicative skills have you noticed in the teacher's work?", "What professional communicative skills are important in your opinion and why?", "Which of these qualities do you personally miss?" During this stage students are able to brainstorm as many ideas as they can and at the end they are able to play an ideal Elementary school teacher demonstrating their high level of professional communicative skills.

The next sub-step is intended to set a goal. It is necessary to choose several goals and test them in the conditional environment in order to reach a reasonable level of professional communicative competence. During this substage, teachers should consider the following options: goal updating (i.e. the development of the qualities or skills); formation (i.e. imitating the specialists' activity in different professional situations); further testing (i.e. thinking about the negative (major, significant) impact on the level of professional communicative competence).

This sub-stage aims to mobilize students' personal qualities in order to compensate undeveloped or poorly developed aspects of their professional communicative competence. The main objective of the second sub-stage is to clarify the internal resources and the potential of future professionals with the help of which they can achieve the required level of professional communicative competence.

The third sub-step is intended to mobilize the students' inner resources and search for their self-realization in various professional situations. This sub-stage aims to exhibit student's behavior in different communicative situations. Students have a great chance to see a close connection between theoretical knowledge and their practical usage during professional activities.

The goal of this sub-step is to stimulate future specialists to make the first attempt at applying their knowledge and abilities in a variety of professional communicative situations. Students have to take the first steps to implement their professional communicative competence in some conventional career situations where they should pay attention to the forecasting and planning their own ways and the consequences of their professional behavior in various situations.

For instance, during classes with the students majoring in "Tourism" they were proposed to use their professional communicative skills in different professional situations, for example, "The hotel client have lost his/her passport, wallet, child, etc.", "The rude client has missed 
his/her flight", etc. These situations were presented to the students with different solutions. The task is to choose, prove and demonstrate one which is the best.

The task of the third stage (final) is consolidation and professionalization of the necessary skills which are used to stimulate students to set new goals and to turn the university students, majoring in different specialities into the learners, bringing about continuous self-improvement. In the final stage teachers should encourage students to develop their own style of behavior in a variety of professional communicative situations. During classes, teachers should help students to demonstrate their ability to achieve the goals in order to compensate poorly formed professional communicative skills.

The students majoring in "Hotel and Catering service" were proposed the business game where they were divided into customers, cooks, waiters, barmen, an owner, manager and administrator. The challenge for each student was to demonstrate the professional communicative competence during the team work. This game helped to demonstrate students' creativity, team spirit and to use their professional communication competence in the process simulating their professional activities.

In order to check the efficiency of the play-based learning activity in the development of students' professional communicative competence we have conducted the experiment, which was held in Luhansk Taras Shevchenko National University (on the basis of Roman and Germanic Philology Department). The study involved 64 second year students of the Foreign Language Department who were divided into two groups: experimental group (32 students) and control group (32 students). The experiment has been implemented during 2016-2017 academic year (the end of 2016-the beginning of 2017).

Before starting the experiment, the students' professional communicative competence was assessed by means of the test which was created on the base of the British Council's - EAQUALS curriculum (European Association for Quality Language Services) (Level B1B2) and the test samples of IELTS for academic purposes. Their results were divided into the following three levels: Low level (the demonstration of elementary level of ne-

\section{BEFORE EXPERIMENT}

$$
\text { - Control group Experimental group }
$$

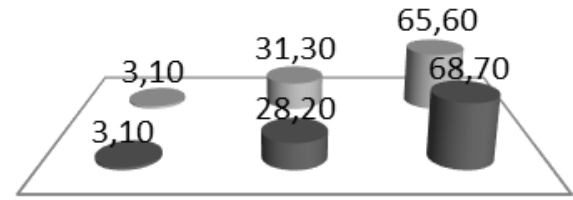

High Level Sufficient Low Level Level

cessary skills or lack of skills, or the presence of students' necessary skills which depend on situational factors, they adapt only in the uncomplicated conditions); Sufficient level (deeper possession of merit, self-organization, the desire to improve professional communicative skills); and High level (self-understanding professional communicative skills, autonomy and self-organization). The results have shown the need to use forms, methods and tools to develop the professional communicative competence within the university course "English for Specific Purposes". That is why play-based learning was implemented to check this hypothesis. So 32 students of the experimental group were involved into the experiment and the students of the control group continued studying in their usual way.

The students of both groups were tested in December 2016 before starting the experiment. The results have shown that before implementing the play-based learning activity within the university course "English for Specific Purposes" there was almost no difference in the levels of the students' professional communicative competence in both groups (see Pic. 1). At the end of the experiment (after the implementation of the play-based learning activity into the educational process of the experimental group) the results have significantly changed. The students of the experimental group reached the High level of the professional communicative competence $(31.30 \%$ of the students), though in the control group only $15.60 \%$ managed to reach it. The difference can be seen in the Sufficient level too. According to the Pic. 1, 62.50\% of the students reached this level in the experimental group and a little lower results were fixed in the control group $(53.10 \%)$. The results are quite clear with the Low level as well. It was found that $31.30 \%$ of the students from the control group after a year of the experiment had this level and fortunately only $6.20 \%$ were assessed to have it in the experimental one. Thus, the efficiency of the play-based learning activity implemented for the university course "English for Specific Purposes" in order to develop the students' professional communicative competence has been proved.

\section{AFTER EXPERIMENT}

Control group $\quad$ Experimental group

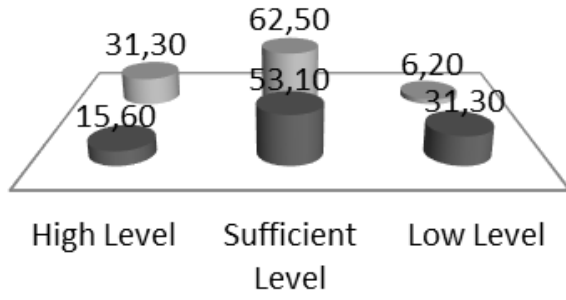

Pic. 1. The level of the development of the students' professional communicative competence (in \%). 


\section{Conclusions}

To sum up, it should be mentioned that the development of the professional communicative competence by means of the play-based activity within the university course "English for specific purposes" (ESP) should be based on the process of individual professional development of every student. The first ("preparation") stage includes students' adaptation to the educational environment at the university and the requirements of the educational process. The second ("education and development") stage aims to analyze students' individual peculiarities and advance strategies of improving the poorly developed professional communicative skills. The third

\section{RFERENCES}

1. Beckham, J. M., \& Watkins, M. (2012). Bringing life to learning: Immersive experiential learning simulations for online and blended courses. The Journal of Asynchronous Learning Networks, 16 (5), 61-70.

2. Ernst, J. V. (2013). Impact of Experiential Learning on Cognitive Outcome in Technology and Engineering Teacher Preparation. The Journal of Technology Education, 24 (2), 31-40.

3. Zafirov, C. (2013). New challenges for the project based learning in the digital age. Trakia Journal of Sciences, 11 (3), 298-302.

4. Herreid, F. H., \& Schiller, N.A. (2013). Case Studies and the Flipped Classroom. The Journal of College Science Teaching, 42, 62-66.

\section{ЛІТЕРАТУРА}

1. Beckham J. M., Watkins M. Bringing life to learning: Immersive experiential learning simulations for online and blended courses / J. M. Beckham, M. Watkins // The Journal of Asynchronous Learning Networks. 2012. - №16 (5). - P. 61-70.

2. Ernst J. V. Impact of Experiential Learning on Cognitive Outcome in Technology and Engineering Teacher Preparation / J. V. Ernst // The Journal of Technology Education. - 2013. - №24 (2). - P. 31-40.

3. Zafirov C. New challenges for the project based learning in the digital age / C. Zafirov // Trakia Journal of Sciences. - 2013. - 11(3). - P. 298-302.

("final") stage aims to professionalize the students' professional communicative competence in order to set new goals, develop their own style of behavior in different professional situations and bring about their continuous self-improvement.

The further studies are supposed to involve the implementation of the play-based learning activity into the curriculum of other courses in order to develop the students' professional communicative competence. Besides, the further research can be also focused on the ways to improve the students' professional communicative competence during their individual work.

5. Dyer, Ronald., (2013). Games in higher education. New pedagogical approaches in game enhanced learning: Curriculum integration. France: Grenoble Ecole de Management.

6. Pavlenko, O. O. (2005). Formuvannia komunikatyvnoi kompetentnosti fakhivtsiv mytnoi sluzhby $\mathrm{v}$ systemi neperervnoi profesiinoi osvity [The Formation of Communicative Competence of Customs Service Specialists in the System of Continuous Professional Education]. Doctor's thesis. Kyiv [in Ukrainian].

7. Verbitskii, A. A. (1991). Aktivnoe obuchenie v vysshei shkole: kontekstnyi podkhod [Active learning in higher education contextual approach]. Moscow: Vysshaia shkola [in Russian].

4. Herreid F. H. Case Studies and the Flipped Classroom / F. H. Herreid, N. A. Schiller // The Journal of College Science Teaching. - 2013. - 42. - P. 62-66.

5. Dyer R. Games in higher education. New pedagogical approaches in game enhanced learning: Curriculum integration / R. Dyer. - France: Grenoble Ecole de Management, 2013. - 266 p.

6. Павленко О. О. Формування комунікативної компетентності фахівців митної служби в системі неперервної професійної освіти : дис. ... д-ра пед. наук : 13.00.04 / О. О. Павленко. - К., 2005. - 447.

7. Вербицкий А. А. Активное обучение в высшей школе: контекстный подход / А. А. Вербицкий. Москва: Высшая школа, 1991. - 207 с.

Тетяна Анатоліївна Кокнова, кандидат педагогічних наук, дочент кафедри романо-германської філології, Д3 «Луганський національний університет імені Тараса Шевченка», 1, площза Гоголя, Старобільськ, Україна

\section{ІМПЛЕМЕНТАЦІЯ НАВЧАЛЬНО-ІГРОВОЇ ДІЯЛЬНОСТІ ЯК ЗАСОБУ ФОРМУВАННЯ ПРОФЕСІЙНОЇ КОМУНІКАТИВНОЇ КОМПЕТЕНТНОСТІ В РАМКАХ УНІВЕРСИТЕТСБКОГО НАВЧАЛЬНОГО КУРСУ «АНГЛІЙСЬКА МОВА ЗА ПРОФЕСІЙНИМ СПРЯМУВАННЯМ»}

Прагнення країн до міжнародного співтовариства підвищує попит у високоякісних спеціалістах, які культурно і політично компетентні у багатьох галузях суспільного життя. Саме тому це дослідження присвячено інноваційному підходові до процесу формування професійної комунікативної компетентності засобами навча- 
льно-ігрової діяльності в рамках університетського курсу «Англійська мова за професійним спрямуванням». Метою статті є підтвердження ефективності імплементації навчально-ігрової діяльності в процесі формування професійної комунікативної компетентності. Для досягнення мети застосовувались такі методи дослідження: теоретичні (аналіз, порівняння, узагальнення, систематизація теоретичних положень для визначення змісту та стану розробленості досліджуваної проблеми використання навчально-ігрової діяльності як засобу формування професійної комунікативної компетентності), емпіричні (діагностичні: анкетування, бесіди; педагогічний експеримент). У дослідженні навчально-ігрова діяльність розуміється як поєднання трьох компонентів: ігрового (стимулює емоційне піднесення учасників, сприяє творчому самовираженню); освітнього (орієнтує студентів на збагачення знань, умінь, навичок і досвіду) та професійного (моделює різні професійні ситуації). Навчальноігрова діяльність підкріплювалась професійними макро та мікро контекстами, що дало змогу поєднати теоретичні знання та їх практичне використання в умовному професійному середовищі. Було дидактично доведено ефективність використання навчально-ігрової діяльності як засобу формування професійної комунікативної компетентності студентів різних спеціальностей. Діагностика рівня сформованості професійної комунікативної компетентності до та після експериментального навчання вказує на позитивну динаміку, що підтверджує ефективність використання навчально-ігрової діяльності як засобу, який сприяє формуванню професійної комунікативної компетентності.

Ключові слова: навчально-ігрова діяльність, педагогічний метод, розвиток професійної комунікативної компетенції, «Англійська мова за професійним спрямуванням», студенти вищих навчальних закладів різних спеціальностей.

Submitted on February, 25, 2017

Reviewed by Doctor of Pedagogy, prof. O. Karaman 